(2) Open Access Full Text Article

REVIEW

\title{
Valium without dependence? Individual GABA receptor subtype contribution toward benzodiazepine addiction, tolerance, and therapeutic effects
}

This article was published in the following Dove Press journal:

Neuropsychiatric Disease and Treatment

\author{
Tianze Cheng' \\ Dominique Marie Wallace ${ }^{2}$ \\ Benjamin Ponteri' \\ Mahir Tuli ${ }^{3}$ \\ 'Pitzer College, Claremont, CA, USA; \\ ${ }^{2}$ Portland State University, Portland, \\ OR, USA; ${ }^{3}$ University of British \\ Columbia, Vancouver, BC, Canada
}

\begin{abstract}
Benzodiazepines are one of the most prescribed medications as first-line treatment of anxiety, insomnia, and epilepsy around the world. Over the past two decades, advances in the neuropharmacological understanding of gamma aminobutyric acid (GABA) $)_{\mathrm{A}}$ receptors revealed distinct contributions from each subtype and produced effects. Recent findings have highlighted the importance of $\alpha_{1}$ containing $\mathrm{GABA}_{\mathrm{A}}$ receptors in the mechanisms of addiction and tolerance in benzodiazepine treatments. This has shown promise in the development of tranquilizers with minimal side effects such as cognitive impairment, dependence, and tolerance. A valium-like drug without its side effects, as repeatedly demonstrated in animals, is achievable.
\end{abstract}

Keywords: benzodiazepines, subtype, tolerance, dependence, anxiolytic, $\mathrm{GABA}_{\mathrm{A}}$ receptor

\section{Introduction}

Benzodiazepines are a class of tranquilizers that enhance gamma aminobutyric acid (GABA)ergic transmission. They are seen ubiquitously in the modern health care system as $>5 \%$ of the total adults in USA are prescribed benzodiazepines each year. ${ }^{1}$ The major behavioral and psychoactive effects of benzodiazepines include anticonvulsive, sedative, muscle relaxant, and anxiolytic effects. ${ }^{2}$ They are readily prescribed by physicians and are regarded as a frontline treatment for many common psychiatric disorders such as anxiety, obsessive-compulsive disorder, seizures, as well as a number of sleep disorders. ${ }^{3}$

Benzodiazepines were discovered in 1955 by chemist Leo Sternbach and, when first introduced, were proposed as a promising replacement for barbiturates, another similar class of tranquilizers that also act on GABA. ${ }^{4,5}$

The medical use of barbiturates was prominent until the 1950s when serious side effects, such as high incidence of abuse, dependence, and overdose finally started to surface. ${ }^{6}$

When benzodiazepines hit the market in the 1960s, they were thought to be the successor to barbiturates due to lower toxicity and side effects. Despite having a lower abuse profile, benzodiazepines still cause dependence after repeated use, which was not widely recognized until the $1980 \mathrm{~s} .^{7,8}$

Many attempts to produce dependence and tolerance-free benzodiazepine drugs have been investigated in the past. The selective agonist zolpidem was marketed, as promising data showed reduced abuse potential. ${ }^{9}$ However, these results did not
Correspondence: Tianze Cheng 221-10, 59th Avenue, Flushing, NY I I 364, USA

Tel + I 646897 I322

Email tcheng@pitzer.edu 
translate in the clinic since zolpidem causes dependence after repeated use. ${ }^{10}$

Studies have also attempted to investigate neuropharmacological mechanisms of benzodiazepines. At first, the benzodiazepine site was categorized into benzodiazepine subtype I and benzodiazepine subtype II, where traditional benzodiazepines bind to both, but triazolopyridazines (TPZs) have high affinity for only type I. ${ }^{11}$ It was later found that TPZ was actually just a selective agonist for one of many subtypes that exist within the $\mathrm{GABA}_{\mathrm{A}}$ receptor family. ${ }^{12}$

Progress in neuropharmacology has revealed various subtypes within the $\mathrm{GABA}_{\mathrm{A}}$ receptor family, as well as anatomical and pharmacological differences between them. Investigations have also been directed toward the addiction and tolerance mechanisms of benzodiazepines; their relationships with specific subtypes within the $\mathrm{GABA}_{\mathrm{A}}$ receptor family will be discussed in further depth.

\section{Pharmacological targets of benzodiazepine}

Benzodiazepines, although referred to as a positive allosteric modulator (PAM) of the $\mathrm{GABA}_{\mathrm{A}}$ receptor, does not actually enhance GABA's binding to the receptor, like conventional PAMs. Benzodiazepines increase the frequency of chloride channel influx which hyperpolarizes the GABA receptor, resulting in increased inhibitory postsynaptic potential. ${ }^{13,14}$

$\alpha_{1-6}, \beta_{1-3}, \gamma_{1-3}, \delta, \varepsilon, \theta$, and $\pi$ make up the currently defined $\mathrm{GABA}_{\mathrm{A}}$ subunits in the human brain. ${ }^{15}$ Classic benzodiazepines such as diazepam binds to $\alpha_{1}, \alpha_{2}, \alpha_{3}$, and $\alpha_{5}$ containing $\mathrm{GABA}_{\mathrm{A}}$ receptors. ${ }^{16} \alpha_{1}$ containing $\mathrm{GABA}_{\mathrm{A}}$ receptors are the most abundant subtype and can be found throughout the brain, while $\alpha_{2}, \alpha_{3}$, and $\alpha_{5}$ subtypes are more region specific. $^{17}$

Although numerous combinations exist, most $\mathrm{GABA}_{\mathrm{A}}$ receptors structurally contain two $\alpha$, two $\beta$, and a single $\gamma$ subunit surrounding a chloride ion channel as shown in Figure $1 .{ }^{18}$ The benzodiazepine site is located between the $\alpha$ and $\gamma$ subunit.

\section{Roles of GABA receptor $\alpha_{1}, \alpha_{2}, \alpha_{3}$, and $\alpha_{5}$ subunits in benzodiazepine pharmacology}

$\mathrm{GABA}_{\mathrm{A}}$ subtype selective compounds and rodent models of subunit point mutation have provided promising data for identifying different subunit contributions toward each clinical effect. We will discuss clinical effects of sedation first, as it impairs the cognitive performance of benzodiazepineprescribed patients. ${ }^{20}$

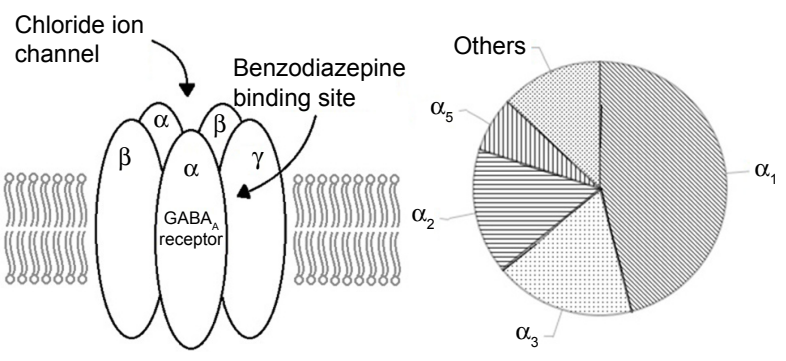

Figure I The GABA receptor and its approximate subtype composition (adapted from Wafford's study).

Note: Data from Wafford. ${ }^{19}$

Abbreviation: GABA, gamma aminobutyric acid.

We know that the $\alpha_{1}$ subtype plays a major role in sedation because $\alpha_{1}(\mathrm{H} 101 \mathrm{R})$ point mutated mice were resilient to sedative effects of benzodiazepines. ${ }^{21}$ Benzodiazepines that possess sparing efficacy at $\alpha_{1}$ subtype such as L-838,417 act as a sedation-free anxiolytic in animal models. ${ }^{21,22}$ L-838,417 has seen popular use in research and is a partial agonist of $\alpha_{2}$, $\alpha_{3}$, and $\alpha_{5}$ containing $\mathrm{GABA}_{\mathrm{A}}$ receptors. ${ }^{22}$ Other compounds with low or absent $\alpha_{1}$ subtype efficacy such as imidazenil, TPA123, and TPA023, are also shown to be sedation-free anxiolytics, revealing the importance of the $\alpha_{1}$ subtype in the mediation of sedation. ${ }^{23,24}$

Moreover, $\alpha_{1}$ subtype selective agonists such as zolpidem are unable to produce anxiolytic effects other than sedation. ${ }^{25}$ The $\alpha_{5}$ inverse agonist, $\alpha 5$ IA, improves memory without producing anxiety, increased awakeness, or proconvulsant effects in animals. ${ }^{26}$ So far, we could conclude that anxiety is mediated by either $\alpha_{2}$ or $\alpha_{3}$ subtypes or both, while sedation is mediated by $\alpha_{1}$ containing $\mathrm{GABA}_{\mathrm{A}}$ receptors.

Because $\alpha 5$ IA reversed alcohol-induced memory deficit when given prior to alcohol administration in humans, $\alpha_{5}$ subtype is thought to contribute toward amnesic effects. ${ }^{26}$ This was further confirmed when the $\alpha_{5}$ subtype was found to be responsible for amnestic effects of $\mathrm{GABA}_{\mathrm{A}}$ receptor PAM etomidate, which correspond with earlier studies on the role of the $\alpha_{5}$ subtype in memory and its anatomical presence in the hippocampus. ${ }^{27}$

However, it seems $\alpha_{5}$ is not the sole subtype that contributes to amnesic effects. $\alpha_{1}$ subtype full agonist zolpidem seemed to produce more memory and cognitive impairment compared to an equivalent dose of triazolam, an agonist of all benzodiazepine sites. ${ }^{28}$ Given that zolpidem produces almost no efficacy at the $\alpha_{5}$ subtype, we can conclude that $\alpha_{1}$ subtype is also involved in amnesic effects of benzodiazepines. ${ }^{28}$

In 2000, it was thought that $\alpha_{2}$ subtype solely mediated anxiolytic actions because only $\alpha_{2}(\mathrm{H} 101 \mathrm{R})$ point mutated mice were still anxious after diazepam treatment. ${ }^{29}$ On the contrary, two studies 5 years later, the first study using 
TP003, an $\alpha_{3}$ subtype selective agonist, demonstrated that TP003 produced strong anxiolytic effects. ${ }^{30}$ The second study used an $\alpha_{3}$ subtype inverse agonist $\alpha 3$ IA to produce anxiogenic effects in mice, further confirming the role of $\alpha_{3}$ subtype in mediating anxiety. ${ }^{31}$

Although $\alpha 3$ IA's weak inverse efficacy at $\alpha_{2}$ subtype could be argued to be anxiogenic, novel non-benzodiazepine compounds such as adipiplon (NG2-73) and SB-205,384 produced anxiolytic effects without any efficacy at the $\alpha_{2}$ subtype. $^{32}$

Moreover, it was shown by data that various novel benzodiazepine compounds with stronger efficacy at $\alpha_{3}$ than $\alpha_{2}$ subtype showed more anxiolytic effects. Löw et al's study received several responses suggesting that the data from elevated plus maze in $\alpha_{2}(\mathrm{H} 101 \mathrm{R})$ mice could be more related and influenced by the motor activity mediated through $\alpha_{2}$ subtype than anxiolysis. . $^{33,34}$

This is important because almost all past models and reviews have categorized the anxiolytic effects of benzodiazepines solely from efficacy at the $\alpha_{2}$ subtype, some further suggesting novel benzodiazepine anxiolytics should be $\alpha_{2}$ selective. ${ }^{35-39}$ However, the most recent investigations on this matter suggest that both $\alpha_{2}$ and $\alpha_{3}$ subtypes mediate anxiety. ${ }^{40,41}$ Therefore, the design of subtype selective benzodiazepine anxiolytics should not be limited to $\alpha_{2}$ containing $\mathrm{GABA}_{\mathrm{A}}$ receptors. This paper will present a revised and comprehensive model of benzodiazepine pharmacology.

$\alpha_{5}$ subtype has also been shown to play a role in mediating anxiety and especially conditioned fear memory, as shown by $\alpha_{5}$ subtype inverse agonists, RY024, and $\alpha_{5}(\mathrm{H} 105 \mathrm{R})$ point mutated mice. ${ }^{42,43}$ However, the $\alpha_{5}$ subtype does not seem to play a major role in mediating anxiety as another $\alpha_{5}$ subtype inverse agonist, $\alpha 5$ IA, does not produce anxiety as assessed by elevated plus maze. ${ }^{44} \alpha_{5}$ subtype also appears to play a minor role in anticonvulsive actions as proconvulsive as $\alpha 5$ IA did not increase seizure thresholds as assessed by pentylenetetrazol. ${ }^{44}$ As a result, the $\alpha_{5}$ subtype most probably mediates a narrow category of anxiety, such as conditioned fear, but could be clinically relevant.

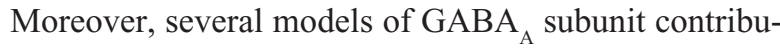
tion in benzodiazepine pharmacology suggest anticonvulsive action only at $\alpha_{1}$ subtype. ${ }^{36}$ TPA023 devoid of activity at the $\alpha_{1}$ subtype was still able to produce anticonvulsive effects, through $\alpha_{2}$ and possibly $\alpha_{3}$ subtype. ${ }^{24}$

Diazepam was anticonvulsive in both $\alpha_{2}(\mathrm{H} 101 \mathrm{R})$ and $\alpha_{3}(\mathrm{H} 126 \mathrm{R})$ mice; however, more $\alpha_{2}(\mathrm{H} 101 \mathrm{R})$ mice convulsed after treatment toward pentylenetetrazol, revealing that the $\alpha_{2}$ subtype contributes more than $\alpha_{3}$ subtype in the anticonvulsant properties of benzodiazepines. ${ }^{29}$
Most anticonvulsive actions of benzodiazepines are mediated by $\alpha_{1}$ as diazepam only mildly attenuated pentylenetetrazol-induced seizures in $\alpha_{1}(\mathrm{H} 101 \mathrm{R})$ mice. However, this data should not discourage anticonvulsant drug discovery that has no efficacy at $\alpha_{1}$ subtype. Recent investigations actually showed that the $\alpha_{1}$ subtype antagonist, $\alpha_{2}, \alpha_{3}$, and $\alpha_{5}$ subtype partial agonist imidazenil was actually more potent than diazepam at attenuating diisopropyl fluorophosphateinduced convulsions and neuronal damage. ${ }^{46}$

Myorelaxation has been identified to involve $\alpha_{2} / \alpha_{3}$ subtype using respective point mutated mice; however, the action appears to be primarily mediated through $\alpha_{2}$ subunit because high doses were needed to induce myorelaxation in the $\alpha_{2}(\mathrm{H} 101 \mathrm{R})$ mice. ${ }^{47} \alpha_{1}$ and $\alpha_{5}$ subtypes might also contribute minorly toward myorelaxation because its respective selective antagonists are able to bluntly alleviate diazepaminduced myorelaxation. ${ }^{48,49}$

Not only does insufficient information support that $\alpha_{2}$ subtype exclusively mediates anxiety, other than a single study, current evidence for the anxiolytic effects of benzodiazepines also points toward a dual contribution from $\alpha_{2}$ and $\alpha_{3}$ subtypes. ${ }^{29-41}$ Therefore, in Table 1 , anxiolytic effects were assigned to both $\alpha_{2} / \alpha_{3}$ containing GABA receptors.

In 2010, in a disappointing human trial on MRK-409, a $\mathrm{GABA}_{\mathrm{A}}$ receptor $\alpha_{2}, \alpha_{3}$, and $\alpha_{5}$ subtype partial agonist that promised to be a sedation-free anxiolytic in animals, demonstrated that its minor agonism on $\alpha_{1}$ subtype produced sedation in humans. ${ }^{54}$ However, the question of whether other subunits were involved in sedation was quickly overthrown as the clinical results of TPA023B, published shortly after, as an $\alpha_{1}$ subtype antagonist and $\alpha_{2} / \alpha_{3}$ subtype partial agonist, produced a sedation-free anxiety suppressing profile, ${ }^{50}$ demonstrating that any efficacy at $\alpha_{1}$ subtype could cause sedation in humans.

$\alpha_{5}$ subtype might be differentially distributed in different sexes. The selective $\alpha_{5}$ subtype allosteric modulator, SH-0532'F-R-CH3, seemed to particularly impact female but not male mice at alleviating stress. ${ }^{55}$ In humans, long-term benzodiazepine use inducing alterations in long-term memory was only significant in women. ${ }^{56}$

Recent advances in novel clinical applications of benzodiazepines revealed densely populated $\alpha_{2}$ containing $\mathrm{GABA}_{\mathrm{A}}$ receptors within the dorsal root involved in relieving pain, in which its inhibitory currents are believed to contribute to nociception. ${ }^{21}$ Furthermore, although $\alpha_{1}$ subtype agonists such as zolpidem and diazepam are efficacious for pain and neuropathy, $\alpha_{2}, \alpha_{3}$ and $\alpha_{5}$ subtype partial agonists seem to produce similar results without the sedative, amnesic, and addictive properties of $\alpha_{1}$ subtype agonists. ${ }^{57,58}$ 
Table I Model of GABA A receptor subtypes and their contribution toward benzodiazepine's psychopharmacological effects

\begin{tabular}{|c|c|c|c|c|}
\hline $\begin{array}{c}\text { Reference } \\
\text { GABA }_{A} \text { Receptor }\end{array}$ & $\begin{array}{c}25,28,35-39,49-52 \\
\alpha 1\end{array}$ & $\begin{array}{c}28,35-39,49-52,64 \\
\alpha 2\end{array}$ & $\begin{array}{c}29-41,50-53,65 \\
\alpha 3\end{array}$ & $\begin{array}{c}26-39,42-49 \\
\alpha 5\end{array}$ \\
\hline Sedation & & & & \\
\hline Addiction & & & & \\
\hline Anxiolysis & & & & \\
\hline Myorelaxation & & & & \\
\hline Anticonvulsive & & & & \\
\hline Amnesia & & & & \\
\hline $\begin{array}{l}\text { Key: } \\
\text { contribution toward } \\
\text { clinical effect }\end{array}$ & Negligible & Minor & Moderate & Significant \\
\hline
\end{tabular}

Abbreviation: GABA, gamma aminobutyric acid.

\section{Mechanism of benzodiazepine addiction}

Benzodiazepine-induced activation of mesolimbic dopamine pathway was observed for the first time in 2009. Benzodiazepine indirectly acts upon the dopaminergic neurons in the ventral tegmental area (VTA), a brain region that plays a major role in addiction and reward. ${ }^{59}$

Both the selective $\alpha_{1}$ subtype agonist zolpidem as well as diazepam were able to modulate glutamatergic transmission upon dopamine neurons in the VTA. This is groundbreaking because zolpidem has a significantly higher affinity toward $\alpha_{1}(\mathrm{Ki}=20 \mathrm{nM})$ containing $\mathrm{GABA}_{\mathrm{A}}$ subtypes than $\alpha_{2}$ and $\alpha_{3}$ $(\mathrm{Ki}=400 \mathrm{nM})$ subtypes, and is almost inactive at $\alpha_{5}{ }^{60}$ This suggests that $\alpha_{1}$ containing $\mathrm{GABA}_{\mathrm{A}}$ receptors unquestionably play a role in addiction.

However, in the same study, diazepam had a significantly higher effect than zolpidem upon VTA; could there be more subtypes than just $\alpha_{1}$ subtype in the role of addiction? The role of $\alpha_{5}$ subtype in addiction was ruled out because $\alpha_{5}$ subtype inverse agonists were unable to prevent self-administration of ethanol. ${ }^{61}$ Another study demonstrated that while $\alpha_{2}, \alpha_{3}$, and $\alpha_{5}$ point mutated mice showed clear preference toward drinking water contaminated with midazolam, $\alpha_{1}(\mathrm{H} 101 \mathrm{R})$ mice did not show any bias between water and midazolam solution, ${ }^{62}$ implying that $\alpha_{1}$ containing $\mathrm{GABA}_{\mathrm{A}}$ receptors are required for addictive behaviors associated with benzodiazepines. Furthermore, $\alpha_{1}$ subtype inactive compounds such as TPA023 show almost no abuse properties. ${ }^{60}$

Recently, opposing evidence has shown that $\alpha_{2}$ and $\alpha_{3}$ subtypes might also be implicated in the addiction of benzodiazepines. After $\alpha_{2}$ subtype within the nucleus accumbens (NAcc) are knockdown in mice, midazolam were no longer reinforcing. Implying that the $\alpha_{2}$ subtype is at least in part involved in the reinforcing effects of benzodiazepines. ${ }^{63}$ Rhesus monkeys with a history of benzodiazepine use, but not cocaine use, have been shown to self-administer $\alpha_{1}$ subtype inactive compound L-838,417 and the $\alpha_{3}$ subtype selective agonist TP003. ${ }^{64}$ These findings hint that the $\alpha_{3}$ containing 


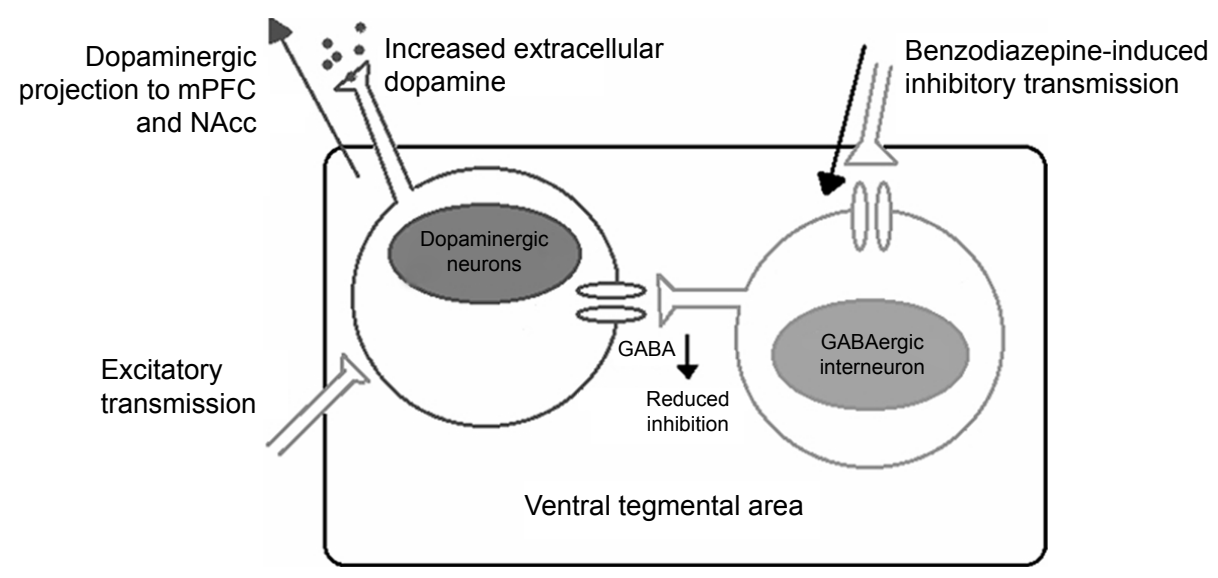

Figure 2 Mechanism of benzodiazepines at VTA.

Note: Data adapted from Rudolph et $\mathrm{al}^{37}$ and Heikkinen et al. ${ }^{59}$

Abbreviations: VTA, ventral tegmental area; GABA, gamma aminobutyric acid; NAcc, nucleus accumbens; mPFC, medial prefrontal cortex.

$\mathrm{GABA}_{\mathrm{A}}$ receptors could be reinforcing in experienced benzodiazepine users. The experienced rhesus monkeys had been previously treated with numerous different benzodiazepines for around 6 months. ${ }^{64}$

The $\alpha_{1}$ containing $\mathrm{GABA}_{\mathrm{A}}$ receptors expressed within the VTA favor its inhibitory projection toward GABA interneurons. ${ }^{62,65}$ With interneurons being responsible for the inhibitory control over dopaminergic neurons of the VTA, inhibiting the inhibition of dopaminergic neurons results in free firing of the dopaminergic neurons. This results in increased dopamine levels as shown in Figure 2. ${ }^{62,65}$ This finding is in congruence with the lack of midazolam self-administration in $\alpha_{1}(\mathrm{H} 101 \mathrm{R})$ mice. ${ }^{62}$ It seems that $\alpha_{1}$ subtype should be completely avoided since even partial agonists at this site could still produce sedation and addiction as seen in bretazenil and MRK-409. ${ }^{54,66}$

The increased AMPA/NMDA ratio in VTA has been shown in another GABA ${ }_{A}$ PAM gaboxadol; however, it does not produce reinforcing effects. ${ }^{67}$ Whether gaboxadol has another mechanism to avert addiction is unclear, but more regions than VTA could be involved. Selective $\alpha_{1}$ subtype antagonist $\beta C C t$ and 3-PBC were shown to be able to prevent the reinforcing effects of alcohol. ${ }^{68,69} \alpha_{1}$ subtype antagonists effectively blocking addictive behaviors in mice indicate that $\alpha_{1}$ containing $\mathrm{GABA}_{\mathrm{A}}$ receptors are highly involved and most likely contribute most or all of the reinforcing effects of GABAergic and benzodiazepine site acting substances. Furthermore, infusions of $\alpha_{1}$ subtype antagonist into the ventral pallidum and extended amygdala, which accommodates a large amount of $\alpha_{1}$ containing GABA $\mathrm{A}_{\mathrm{A}}$ receptors, resulted in a reduction in ethanol-induced addictive behaviors. ${ }^{68,70}$

Opioid mechanisms are associated with reward pathways and a study has shown the competitive opioid receptor antagonist naloxone attenuating the addictive properties of benzodiazepines. ${ }^{71}$ However, more studies opposing the above study have been published. Interestingly, naloxone is able to block anxiolytic and sedative properties of benzodiazepines. ${ }^{72}$ More recent studies showed that opioid peptides are involved in benzodiazepine's anxiolytic rather than addictive effects. ${ }^{73}$

The role of nicotinic acetylcholine receptor (nAChR), especially the $\alpha 4 \beta 2$ subtype, has been highlighted in drug addiction. ${ }^{74}$ Since nAChR is a major modulator of GABA release in regions such as the thalamus, hippocampus, and VTA ${ }^{68,75}$ there is surprisingly less research in this direction. Is there really no link between acetylcholine and benzodiazepine addiction?

nAChRs, especially the $\alpha 4 \beta 2$ subtype, are upregulated after chronic exposure to drugs such as nicotine. ${ }^{76}$ This phenomenon is also seen in naloxone-induced morphine withdrawal, alcohol withdrawal, and what we're interested in: flumazenil-induced benzodiazepine withdrawal. ${ }^{77,78}$

Most interestingly, this acetylcholine release was not seen in the partial agonists imidazenil and abecarnil, which has no efficacy at the $\alpha_{1}$ subtype. $^{79}$ The fact that benzodiazepine withdrawal is marked by an acetylcholine increase in the nucleus accumbens, which is also seen in other drug withdrawals, further begs clarification of the benzodiazepineacetylcholine affiliation, and possibly of subunit-specific involvement, which has been overlooked. ${ }^{78,79}$

Although a recent primate study showed that $\alpha_{3}$ subtype might be reinforcing in those who are already dependent, $\alpha_{1}$ containing $\mathrm{GABA}_{\mathrm{A}}$ receptors contribute to most if not all of the reinforcing effects of benzodiazepines.

\section{Mechanisms of benzodiazepine tolerance}

Efficacy of benzodiazepine progressively reduces after longterm exposure; not only is a higher dosage of the drug required 
to experience the same therapeutic effects, but also discontinuation of prolonged treatment induces withdrawal. ${ }^{80}$

A simple way to explain tolerance to any drug is downregulation of the receptor as the aftermath of neuroplasticity. However, it is demonstrated that even after chronic administration of benzodiazepines, the number of benzodiazepine sites is not reduced, neither is the sensitivity of the benzodiazepine site..$^{81,82}$

Benzodiazepine site downregulation does not seem to happen unless astronomical doses are given, in many studies over $100 \mathrm{mg} / \mathrm{kg}$ in rats, which translated into human doses that are far above the therapeutic range. ${ }^{83,84}$ Not to mention, only inconclusive and inconsistent results have been presented regarding possible changes in subtype composition and their mRNA expression. ${ }^{85,86}$ So, if its not downregulation, what is the underlying mechanism?

While tolerance to sedative and anticonvulsant effects seems to build quickly in both humans and animal models, a lack of tolerance regarding the anxiolytic and amnesic effects of long-term benzodiazepine use has been consistently demonstrated in clinical trials. ${ }^{87-89}$

Diazepam and alprazolam for the treatment of panic attacks, social phobia, and other anxiety-related disorders are effective even after chronic use. ${ }^{90,91}$ Could this mean $\alpha_{2}$ and $\alpha_{3}$ containing $\mathrm{GABA}_{\mathrm{A}}$ receptors, which mediate anxiety, have less significance in the tolerance building mechanism of benzodiazepines?

Other than putting the blame of addiction on $\alpha_{1}$ subtype, $\alpha_{5}$ subtype might be required for tolerance toward sedative effects of benzodiazepines. With the guidance of $\alpha_{1}, \alpha_{2}, \alpha_{3}$, and $\alpha_{5}$ subtype point mutated mice, repetitive dosing of diazepam showed that $\alpha_{5}$ containing $\mathrm{GABA}_{\mathrm{A}}$ receptors of the dentate gyrus lead the adaptive changes associated with sedative tolerance to benzodiazepines. ${ }^{92}$ After chronic benzodiazepine administration, mice of the $\alpha_{5}$ point mutated species retained most of the motor-depressant effects of benzodiazepines, whereas $\alpha_{1}, \alpha_{2}$, and $\alpha_{3}$ point mutated mice started habituating from the sedative effects of benzodiazepines. ${ }^{92}$

Now one might ask, how would you then explain tolerance of zolpidem since it has no $\alpha_{5}$ subtype efficacy? Well, in the same study, $\alpha_{1}(\mathrm{H} 101 \mathrm{R})$ mice showed downregulation of $\alpha_{5}$ containing $\mathrm{GABA}_{\mathrm{A}}$ receptors in the dentate gyrus of the hippocampus, but not in $\alpha_{2}$ and $\alpha_{3}$ point mutated mice. ${ }^{92}$ Therefore, a hypothesis that the involvement of $\alpha_{5}$ as well as $\alpha_{1}$ subtypes is required to induce tolerance in benzodiazepine use was put forward.

Although long-term benzodiazepine treatment did not reduce the number of benzodiazepine sites or alter the binding affinity as assessed by ${ }^{3} \mathrm{H}$-flumazenil, ${ }^{93}$ it did downregulate adenosine receptors in the striatum by almost half in mice of the same investigation. It has been consistently shown that benzodiazepine use is associated with downregulation of adenosine $A_{1}$ and $A_{2}$ receptors in animals. ${ }^{94,95}$ Although the mechanism of how benzodiazepines can influence adenosine receptors is unclear, a possible explanation for the downregulation of adenosine is for the attenuation of benzodiazepine-induced sedation.

It has been proven that benzodiazepines can indirectly increase adenosine after acute administration, through inhibition of adenosine reuptake. The adenosine reuptake inhibitor dipyridamole and the adenosine deaminase EHNA were able to reverse the sedative effects of benzodiazepines, as measured by excitatory currents within the hippocampus. ${ }^{96}$ This mechanism was recently further validated when the sedative effects of benzodiazepines, barbiturates, and propofol all appeared to be mediated by the adenosine system..$^{97}$ Downregulation of adenosine receptors as discussed could in part explain the tolerance to the sedative effects of benzodiazepines.

It came forth that not only adenosine is involved in the tolerance toward benzodiazepines. NDMA and AMPA receptor upregulation was observed in the cerebral cortex of mice after abrupt ending of chronic diazepam administration. ${ }^{98,99}$ More recent inspections of this mechanism showed comparable results especially in the rat hippocampus. ${ }^{100,101}$

It appears that NMDA upregulation happens acutely after benzodiazepine administration, because NMDA antagonists dizocilpine (MK-801) and CPP were able to prevent tolerance to sedative and withdrawal effects after benzodiazepine administration. ${ }^{102,103}$ While the NMDA antagonist can suppress withdrawal symptoms in acute benzodiazepine abstinence, the AMPA antagonist prevented withdrawal during the long-term phase in mice. ${ }^{104,105}$ The upregulation and changes of glutamatergic system are most likely a compensatory mechanism.

Numerous investigations have observed uncoupling between allosteric linkage of GABA and the benzodiazepine site. Uncoupling is a mechanism wherein the benzodiazepine site loses its allosteric modulatory effects over GABAergic activities. ${ }^{18,89}$ It explains the reduced efficacy of benzodiazepines after chronic use and is further verified in numerous in vivo demonstrations. ${ }^{89}$ Benzodiazepine site uncoupling is associated with negative modulation of GABAergic transmission and is likely a result of compensation to suppress repeated benzodiazepine-induced GABAergic enhancement. ${ }^{106}$

In rats continuously exposed to either full agonist, partial agonist, or the antagonist flumazenil, the benzodiazepine efficacy correlates to the degree of uncoupling. Full agonists resulted in the highest percentage of benzodiazepine site 
uncoupling, especially in benzodiazepine sites that regulated anticonvulsant actions. ${ }^{107}$ This not only explains the rapid tolerance building toward anticonvulsant effects but also indicates that partial agonists may be able to produce less tolerance.

Interestingly, a single flumazenil dose can reverse the anticonvulsant tolerance after chronic benzodiazepine exposure. ${ }^{108,109}$ The mechanisms of how flumazenil completely reverses the allosteric uncoupling of benzodiazepine and GABA are unclear. Flumazenil appears to be capable of yielding opposite downstream mechanisms of benzodiazepine agonists, and actually upregulate benzodiazepine binding and GABAergic chloride uptake. ${ }^{110}$ Similar results have been observed in clinics, where flumazenil was able to reverse tolerance of daily clonazepam in users with partial seizures, who have been taking the medication for over a year. ${ }^{111,112}$

Benzodiazepine uncoupling recovers after 2 days of abstinence in rats, and only happens after repeated administration. ${ }^{113}$ This correlates with previously mentioned human clinical data in terms of the quick adaptations to benzodiazepine's anticonvulsant tolerance. Because about one third of all postsynaptic $\mathrm{GABA}_{\mathrm{A}}$ receptors are continuously activated, uncoupling might impact continual GABA transmission, which could also contribute to withdrawal. ${ }^{114}$

In chick cortical neurons, benzodiazepine treatment leads to mild reductions of $\mathrm{GABA}_{\mathrm{A}}$ receptors on membrane surface; these missing receptors are discovered intracellularly and contribute around $7 \%$ of all $\mathrm{GABA}_{\mathrm{A}}$ receptors. ${ }^{115}$ Tehrani et al also demonstrated that these intracellular $\mathrm{GABA}_{\mathrm{A}}$ receptors located on clathrin-bound vesicles are uncoupled as benzodiazepine sites with reduced affinity and allosteric modulatory control over the receptor. ${ }^{116-118}$

Long-term benzodiazepine treatment caused a significant $83 \%$ increase in the number of $\mathrm{GABA}_{\mathrm{A}}$ receptors on clathrin-coated vesicles versus control. Although benzodiazepines are still able to bind at these sites, they produce no modulatory effect. The internalization also meant a $12 \%$ reduction of $\mathrm{GABA}_{\mathrm{A}}$ receptors located on synaptic membranes, as assessed by ${ }^{3} \mathrm{H}$-flunitrazepam after a 7-day benzodiazepine treatment. ${ }^{118}$

This internalization of $\mathrm{GABA}_{\mathrm{A}}$ receptors at the synaptic membrane possibly contributes to the tolerance of benzodiazepines. Although benzodiazepine agonists are able to bind to intracellular GABA receptors, they produce little or no allosteric modulation. A recent examination of benzodiazepine allosteric uncoupling has shown that benzodiazepine site internalization is part of the uncoupling mechanism. ${ }^{114}$ This finding is likely the observation of benzodiazepine sites located on clathrin vesicles.
Considerable evidence has been compiled recently underlying a complete and complex molecular mechanism of phosphorylation and posttranslational modifications of $\mathrm{GABA}_{\mathrm{A}}$ as a response to benzodiazepines that possibly contribute to the observed uncoupling and tolerance building mechanism. ${ }^{119}$ These complex molecular mechanisms of posttranslational modifications of the $\mathrm{GABA}_{\mathrm{A}}$ receptor resulting from palmitoylation, ubiquitination, and especially phosphorylation, are believed to dictate the role in regulating the recycling of $\mathrm{GABA}_{\mathrm{A}}$ receptors through different protein kinases and ultimately impact inhibitory currents. ${ }^{18,84,119}$

cAMP-dependent protein kinase A (PKA) has been identified to lead the changes and alterations of $\mathrm{GABA}_{\mathrm{A}}$ receptor functioning of CA1 pyramidal cells within the hippocampus after long-term flurazepam administration. ${ }^{120}$ Further evidence accumulated over the importance of PKA in the formation of benzodiazepine tolerance showed that mutations to a single PKA phosphorylation site prevented uncoupling, even after chronic diazepam treatment. ${ }^{121}$

As compared to wild-type mice, a wide range of transcripts that are thought to contribute to the neuroplastic mechanisms of tolerance remained unchanged in $\alpha_{1}(\mathrm{H} 101 \mathrm{R})$ point mutated mice after diazepam administration. ${ }^{122}$ Transcripts changes such as brain-derived neurotrophic factor and calcium/calmodulin-dependent kinase II play important roles in synaptic plasticity; $\alpha_{1}(\mathrm{H} 101 \mathrm{R})$ mice did not produce transcript changes after diazepam treatment. ${ }^{122}$ This is direct evidence regarding the involvement of $\alpha_{1}$ containing $\mathrm{GABA}_{\mathrm{A}}$ receptors in the role of benzodiazepine tolerance. It agrees with earlier studies wherein $\alpha_{1}$ subtype inactive benzodiazepines imidazenil and TPA023 consistently failed to show anticonvulsant tolerance in chronic dosing in mice and monkeys. ${ }^{123-129}$

Interestingly, there seems to be almost no downregulation of $\mathrm{GABA}_{\mathrm{A}}$ receptors despite long-term heavy administration of imidazenil as compared to diazepam. ${ }^{83}$ Future studies could compare the uncoupling and posttranslational modification differences between traditional benzodiazepine agonists such as diazepam and $\alpha_{1}$ subtype ineffective compounds like TPA023 and imidazenil.

\section{Conclusion}

Although partial agonism at $\alpha_{1}$ containing $\mathrm{GABA}_{\mathrm{A}}$ receptors appears to reduce abuse potential, it appears insufficient. Bretazenil and etizolam which showed reduced abuse potential in animal models do not keep their promise. ${ }^{129,130}$ When the bretazenil dose increased from 2 to $4 \mathrm{mg}$ in humans, users reported liking the drug. While etizolam has seen popular 
recreational use, it is sold online as a research chemical capable of inducing euphoria. ${ }^{131}$ As a result, if clinical effects can be achieved without the involvement of $\alpha_{1}$ subtype, it should be avoided in future drug design of benzodiazepines and similar compounds.

As already discussed, both $\alpha_{2}$ and $\alpha_{3}$ containing GABA receptors and their involvement in anxiety suppressing effects of benzodiazepines are critical. This is because most current models have characterized $\alpha_{2}$ containing GABA $\mathrm{A}_{\mathrm{A}}$ receptors as the sole mediator of anxiety in benzodiazepines. ${ }^{35-39}$ As highlighted in the model presented in this review, the search for a selective anxiolytic should not be constrained to $\alpha_{2}$ selective. ${ }^{29-41}$

Benzodiazepine tolerance is complicated and appears to result from a combination of various factors. Complex mechanisms involving uncoupling, intracellular trafficking, posttranslational modifications of $\mathrm{GABA}_{\mathrm{A}}$ receptors all appear to contribute toward benzodiazepine tolerance. ${ }^{89,119}$ Various studies have also suggested the involvement of other neurotransmitters, especially adenosine and glutamate, during the tolerance and withdrawal effects of benzodiazepines. ${ }^{92-105}$

The efficacy of benzodiazepines may also play a role in tolerance as full agonists produce more tolerance than partial agonists. ${ }^{107}$

In the light of current evidence, $\alpha_{1}$ dormant, $\alpha_{2}, \alpha_{3}$, and $\alpha_{5}$ subtype partial agonists not only possess low abuse potential, but are also low or devoid of tolerance building. There is evidence that $\alpha_{1}$ containing $\mathrm{GABA}_{\mathrm{A}}$ receptors directly contribute to the downstream effects of tolerance, because $\alpha_{1}(\mathrm{H} 101 \mathrm{R})$ mice have been shown to maintain expressions in neuroplasticity-coding transcripts after diazepam administration. ${ }^{120}$ This perfectly agrees with data from animal studies regarding the lack of tolerance in $\alpha_{1}$ subtype inactive compounds such as TPA023B and imidazenil. ${ }^{121-126}$ Future drug discovery involving tranquilizers should look for partial agonists of $\alpha_{2}, \alpha_{3}$, and $\alpha_{5}$ containing GABA receptors; Valium without its side effects is potentially achievable.

\section{Disclosure}

The authors report no conflicts of interest in this work.

\section{References}

1. Olfson M, King M, Schoenbaum M. Benzodiazepine use in the United States. JAMA Psychiatry. 2015;72(2):136-142.

2. Dantzer R. Behavioral effects of benzodiazepines: a review. Neurosci Biobehav Rev. 1977;1(2):71-86.

3. Shader R, Greenblatt D, Balter M. Appropriate use and regulatory control of benzodiazepines. J Clin Pharmacol. 1991;31(9):781-784.

4. Sternbach L. The benzodiazepine story. J Med Chem. 1979;22(1):1-7.
5. Olsen R, Wamsley J, Lee R, Lomax P. Benzodiazepine/barbiturate/ GABA receptor-chloride ionophore complex in a genetic model for generalized epilepsy. Adv Neurol. 1986;44:365-378.

6. Harris I. Addiction to barbiturates and the barbiturate abstinence syndrome. Ann Intern Med. 1950;33(1):108-121.

7. Wolf B, Grohmann R, Biber D, Brenne P, Rüther E. Benzodiazepine abuse and dependence in psychiatric inpatients. Pharmacopsychiatry. 1989;22(2):54-60.

8. Busto U, Sellers E, Naranjo C, Cappell H, Sanchez-Craig M, Simpkins J. Patterns of benzodiazepine abuse and dependence. Addiction. 1986; 81(1):87-94.

9. Perrault G, Morel E, Sanger D, Zivkovic B. Lack of tolerance and physical dependence upon repeated treatment with the novel hypnotic zolpidem. J Pharmacol Exp Ther. 1992;263(1):298-303.

10. Victorri-Vigneau C, Dailly E, Veyrac G, Jolliet P. Evidence of zolpidem abuse and dependence: results of the French Centre for Evaluation and Information on Pharmacodependence (CEIP) network survey. Br J Clin Pharmacol. 2007;64(2):198-209.

11. Klepner C, Lippa A, Benson D, Sano M, Beer B. Resolution of two biochemically and pharmacologically distinct benzodiazepine receptors. Pharmacol Biochem Behav. 1979;11(4):457-462.

12. Atack J. Regional differences in the inhibition of mouse in vivo [3H] Ro 15-1788 binding reflect selectivity for $\alpha 1$ versus $\alpha 2$ and $\alpha 3$ subunitcontaining GABAA receptors. Neuropsychopharmacology. 1999;20(3): 255-262.

13. Sieghart W. GABAA receptors: ligand-gated $\mathrm{Cl}-$ ion channels modulated by multiple drug-binding sites. Trends Pharmacol Sci. 1992;13(12): 446-450.

14. Study R, Barker J. Diazepam and (-)-pentobarbital: fluctuation analysis reveals different mechanisms for potentiation of gamma-aminobutyric acid responses in cultured central neurons. Proc Natl Acad Sci U S A. 1981;78(11):7180-7184.

15. Sieghart W, Sperk G. Subunit composition, distribution and function of GABA-A receptor subtypes. Curr Top Med Chem. 2002;2(8): 795-816.

16. Rudolph U, Crestani F, Benke D, et al. Benzodiazepine actions mediated by specific gamma-aminobutyric acid(A) receptor subtypes. Nature. 1999;401(6755):796-800.

17. Fritschy J, Mohler H. GABAA-receptor heterogeneity in the adult rat brain: differential regional and cellular distribution of seven major subunits. J Comp Neurol. 1995;359(1):154-194.

18. Vinkers C, Olivier B. Mechanisms underlying tolerance after long-term benzodiazepine use: a future for subtype-selective receptor modulators? Adv Pharmacol Sci. 2012;2012:1-19.

19. Wafford K. GABAA receptor subtypes: any clues to the mechanism of benzodiazepine dependence? Curr Opin Pharmacol. 2005;5(1): $47-52$.

20. Hindmarch I, Trick L, Ridout F. A double-blind, placebo- and positive-internal-controlled (alprazolam) investigation of the cognitive and psychomotor profile of pregabalin in healthy volunteers. Psychopharmacology. 2005;183(2):133-143.

21. McKernan R, Rosahl T, Reynolds D, et al. Sedative but not anxiolytic properties of benzodiazepines are mediated by the GABAA receptor $\alpha 1$ subtype. Nat Neurosci. 2000;3(6):587-592.

22. Knabl J, Witschi R, Hösl K, et al. Reversal of pathological pain through specific spinal GABAA receptor subtypes. Nature. 2008; 451(7176):330-334.

23. Auta J, Kadriu B, Giusti P, Costa E, Guidotti A. Anticonvulsant, anxiolytic, and non-sedating actions of imidazenil and other imidazobenzodiazepine carboxamide derivatives. Pharmacol Biochem Behav. 2010;95(4):383-389.

24. Atack J. TPA023 [7-(1,1-Dimethylethyl)-6-(2-ethyl-2H-1,2,4-triazol3-ylmethoxy)-3-(2-fluorophenyl)-1,2,4-triazolo[4,3-b]pyridazine], an agonist selective for $\alpha 2$ - and $\alpha 3$-containing GABAA receptors, is a nonsedating anxiolytic in rodents and primates. J Pharmacol Exp Ther. 2005;316(1):410-422. 
25. Huang M, Radadia K, Macone B, Auerbach S, Datta S. Effects of eszopiclone and zolpidem on sleep-wake behavior, anxiety-like behavior and contextual memory in rats. Behav Brain Res. 2010;210(1):54-66.

26. Atack J. GABAA receptor subtype-selective efficacy: TPA023, an $\alpha 2 / \alpha 3$ selective non-sedating anxiolytic and $\alpha 5$ IA, an $\alpha 5$ selective cognition enhancer. CNS Drug Rev. 2008;14(1):25-35.

27. Cheng V, Martin J, Erin M, et al. $\alpha 5$ GABAA receptors mediate the amnestic but not sedative-hypnotic effects of the general anesthetic etomidate. J Neurosci. 2006;26(14):3713-3720.

28. Roehrs T, Merlotti L, Zorick F, Roth T. Sedative, memory, and performance effects of hypnotics. Psychopharmacology. 1994;116(2): $130-134$.

29. Löw K, Crestani F, Keist R, et al. Molecular and neuronal substrate for the selective attenuation of anxiety. Science. 2000;290(5489):131-134.

30. Dias R. Evidence for a significant role of $\alpha 3$-containing GABAA receptors in mediating the anxiolytic effects of benzodiazepines. J Neurosci. 2005;25(46):10682-10688.

31. Atack J, Hutson P, Collinson N, et al. Anxiogenic properties of an inverse agonist selective for $\alpha 3$ subunit-containing GABAA receptors. Br J Clin Pharmacol. 2005;144(3):357-366.

32. Navarro J, Burón E, Martín-López M. Anxiolytic-like activity of SB-205384 in the elevated plus-maze test in mice. Psicothema. 2006; 18(1):100-104.

33. Crestani F, Möhler H, Rudolph U. Anxiolytic-like action of diazepam: mediated by GABAA receptors containing the $\alpha 2$-subunit. Trends Pharmacol Sci. 2001;22(8):403.

34. Reynolds D, McKernan R, Dawson G. Anxiolytic-like action of diazepam: which GABAA receptor subtype is involved? Trends Pharmacol Sci. 2001;22(8):402.

35. Rudolph U, Crestani F, Möhler H. GABAA receptor subtypes: dissecting their pharmacological functions. Trends Pharmacol Sci. 2001; 22(4):188-194.

36. Tan K, Rudolph U, Lüscher C. Hooked on benzodiazepines: GABAA receptor subtypes and addiction. Trends Neurosci. 2011;34(4):188-197.

37. Rudolph U, Knoflach F. Beyond classical benzodiazepines: novel therapeutic potential of GABAA receptor subtypes. Nat Rev Drug Discov. 2011;10(9):685-697.

38. Samardzic J, Svob Strac D. Benzodiazepines and anxiety disorders: from laboratory to clinic. New Developments in Anxiety Disorders. Croatia, Rijeka: InTech; 2016.

39. Mirza N, Munro G. The role of GABA(A) receptor subtypes as analgesic targets. Drug News Perspect. 2010;23(6):351-360.

40. McEown K, Treit D. $\alpha 2$ GABAA receptor sub-units in the ventral hippocampus and $\alpha 5$ GABAA receptor sub-units in the dorsal hippocampus mediate anxiety and fear memory. Neuroscience. 2013;252:169-177.

41. Morris H, Dawson G, Reynolds D, Atack J, Stephens D. Both $\alpha 2$ and $\alpha 3$ GABAA receptor subtypes mediate the anxiolytic properties of benzodiazepine site ligands in the conditioned emotional response paradigm. Eur J Neurosci. 2006;23(9):2495-2504.

42. Bailey D, Tetzlaff J, Cook J, He X, Helmstetter F. Effects of hippocampal injections of a novel ligand selective for the $\alpha 5 \beta 2 \gamma 2$ subunits of the GABA/benzodiazepine receptor on Pavlovian conditioning. Neurobiol Learn Mem. 2002;78(1):1-10.

43. Crestani F, Keist R, Fritschy J, et al. Trace fear conditioning involves hippocampal $\alpha 5$ GABAA receptors. Proc Natl Acad Sci U S A. 2002; 99(13):8980-8985.

44. Dawson G, Maubach KA, Collinson N, et al. An inverse agonist selective for $\alpha 5$ subunit-containing GABAA receptors enhances cognition. J Pharmacol Exp Ther. 2005;316(3):1335-1345.

45. Rudolph U, Crestani F, Benke D, et al. Benzodiazepine actions mediated by specific gamma-aminobutyric acid(A) receptor subtypes. Nature. 1999;401(6755):796-800.

46. Kadriu B, Guidotti A, Costa E, Auta J. Imidazenil, a non-sedating anticonvulsant benzodiazepine, is more potent than diazepam in protecting against DFP-induced seizures and neuronal damage. Toxicology. 2009;256(3):164-174.
47. Crestani F, Löw K, Keist R, Mandelli M, Möhler H, Rudolph U. Molecular targets for the myorelaxant action of diazepam. Mol Pharmacol. 2001;59(3):442-445.

48. Milić M, Divljaković J, Rallapalli S, van Linn M, Timić T, Cook J, Savić M. The role of $\alpha 1$ and $\alpha 5$ subunit-containing GABAA receptors in motor impairment induced by benzodiazepines in rats. Behav Pharmacol. 2012;23(2):191-197.

49. Licata S, Platt D, Cook J, Van Linn M, Rowlett J. Contribution of $\alpha 1$ subunit-containing $\gamma$-aminobutyric acid A (GABAA) receptors to motor-impairing effects of benzodiazepines in squirrel monkeys. Psychopharmacology. 2008;203(3):539-546.

50. Atack J, Wafford K, Street L, et al. MRK-409 (MK-0343), a GABAA receptor subtype-selective partial agonist, is a non-sedating anxiolytic in preclinical species but causes sedation in humans. J Psychopharmacol. 2010;25(3):314-328.

51. Ator N, Atack J, Hargreaves R, Burns H, Dawson G. Reducing abuse liability of GABAA/benzodiazepine ligands via selective partial agonist efficacy at $\alpha 1$ and $\alpha 2 / 3$ subtypes. J Pharmacol Exp Ther. 2009; 332(1):4-16.

52. Rowlett J, Platt D, Lelas S, Atack J, Dawson G. Different GABAA receptor subtypes mediate the anxiolytic, abuse-related, and motor effects of benzodiazepine-like drugs in primates. Proc Natl Acad Sci US A. 2005;102(3):915-920.

53. Fischer B, Atack J, Platt D, Reynolds D, Dawson G, Rowlett J. Contribution of GABAA receptors containing $\alpha 3$ subunits to the therapeuticrelated and side effects of benzodiazepine-type drugs in monkeys. Psychopharmacology. 2010;215(2):311-319.

54. Atack J, Hallet DJ, Tye S, et al. Preclinical and clinical pharmacology of TPA023B, a GABAA receptor $\alpha 2 / \alpha 3$ subtype-selective partial agonist. J Psychopharmacol. 2010;25(3):329-344.

55. Piantadosi S, French B, Poe M, et al. Sex-dependent anti-stress effect of an $\alpha 5$ subunit containing GABAA receptor positive allosteric modulator. Front Pharmacol. 2016;7:446.

56. Boeuf-Cazou O, Bongue B, Ansiau D, Marquié J, Lapeyre-Mestre M. Impact of long-term benzodiazepine use on cognitive functioning in young adults: the VISAT cohort. Eur J Clin Pharmacol. 2011;67(10): 1045-1052.

57. Moldofsky H, Lue F, Mously C, Roth-Schechter B, Reynolds W. The effect of zolpidem in patients with fibromyalgia: a dose ranging, double blind, placebo controlled, modified crossover study. J Rheumatol. 1996; 23(3):529-533.

58. Nickolls S, Mace H, Fish R, et al. A comparison of the $\alpha 2 / 3 / 5$ selective positive allosteric modulators L-838,417 and TPA023 in preclinical models of inflammatory and neuropathic pain. Adv Pharmacol Sci. 2011; 2011:1-12.

59. Heikkinen A, Möykkynen T, Korpi E. Long-lasting modulation of glutamatergic transmission in VTA dopamine neurons after a single dose of benzodiazepine agonists. Neuropsychopharmacology. 2009; 34(2):290-298.

60. Crestani F, Martin J, Möhler H, Rudolph U. Mechanism of action of the hypnotic zolpidem in vivo. Br J Clin Pharmacol. 2000;131(7):1251-1254.

61. Stephens D, Pistovcakova J, Worthing L, Atack J, Dawson G. Role of GABAA $\alpha 5$-containing receptors in ethanol reward: the effects of targeted gene deletion, and a selective inverse agonist. Eur J Pharmacol. 2005;526(1-3):240-250.

62. Tan K, Brown M, Labouèbe G, et al. Neural bases for addictive properties of benzodiazepines. Nature. 2010;463(7282):769-774.

63. Engin E, Bakhurin K, Smith K, et al. Neural Basis of Benzodiazepine Reward: Requirement for $\alpha 2$ Containing GABAA Receptors in the Nucleus Accumbens. Neuropsychopharmacology. 2012;39(8):1805-1815.

64. Shinday N, Sawyer E, Fischer B, et al. Reinforcing effects of compounds lacking intrinsic efficacy at $\alpha 1$ subunit-containing GABAA receptor subtypes in midazolam- but not cocaine-experienced rhesus monkeys. Neuropsychopharmacology. 2012;38(6):1006-1014.

65. Lalive A, Rudolph U, Lüscher C, Tan K. Is there a way to curb benzodiazepine addiction? Swiss Med Wkly. 2011;141:w13277. 
66. Busto U, Kaplan H, Zawertailo L, Sellers E. Pharmacologic effects and abuse liability of bretazenil, diazepam, and alprazolam in humans. Clin Pharmacol Ther. 1994;55(4):451-463.

67. Vashchinkina E, Panhelainen A, Vekovischeva O, et al. GABA site agonist gaboxadol induces addiction-predicting persistent changes in ventral tegmental area dopamine neurons but is not rewarding in mice or baboons. J Neurosci. 2012;32(15):5310-5320.

68. Harvey S, Foster K, McKay P, et al. The GABAA receptor $\alpha 1$ subtype in the ventral pallidum regulates alcohol-seeking behaviors. J Neurosci. 2002;22(9):3765-3775.

69. Kaminski B, Van Linn M, Cook J, Yin W, Weerts E. Effects of the benzodiazepine GABAA $\alpha 1$-preferring ligand, 3-propoxy- $\beta$-carboline hydrochloride (3-PBC), on alcohol seeking and self-administration in baboons. Psychopharmacology. 2012;227(1):127-136.

70. Eiler W, June H. Blockade of GABAA receptors within the extended amygdala attenuates D2 regulation of alcohol-motivated behaviors in the ventral tegmental area of alcohol-preferring $(\mathrm{P})$ rats. Neuropharmacology. 2007;52(8):1570-1579.

71. Cooper SJ. Benzodiazepine-opiate antagonist interactions and reward processes: implications for drug dependency. Neuropharmacology. 1983;22(4):535-538.

72. Solhi H, Mostafazadeh B, Reza KVH, Reza GA, Shooshtarizadeh A. Benefit effect of naloxone in benzodiazepines intoxication: findings of a preliminary study. Hum Exp Toxicol. 2010;30(7):535-540.

73. Kang W, Steven W, Marlene W. Overexpression of proenkephalin in the amygdala potentiates the anxiolytic effects of benzodiazepines. Neuropsychopharmacology. 2000;22(1):77-88.

74. Connolly J, Boulter J, Heinemann S. $\alpha 4-\beta 2$ and other nicotinic acetylcholine receptor subtypes as targets of psychoactive and addictive drugs. Br J Clin Pharmacol. 1992;105(3):657-666.

75. Sher T, Chen Y, Sharples TJ, et al. Physiological roles of neuronal nicotinic receptors subtypes: new insights on the nicotinic modulation of neurotransmitter release, synaptic transmission and plasticity. Curr Top Med Chem. 2003;4(3):283-297.

76. Buisson B, Bertrand D. Nicotine addiction: the possible role of functional upregulation. Trends Pharmacol Sci. 2002;23(3):130-136.

77. Williams M, Adinoff B. The role of acetylcholine in cocaine addiction. Neuropsychopharmacology. 2007;33(8):1779-1797.

78. Rada P, Hoebel B. Acetylcholine in the accumbens is decreased by diazepam and increased by benzodiazepine withdrawal: a possible mechanism for dependency. Eur J Pharmacol. 2005;508(1-3): 131-138.

79. Dazzi L, Motzo C, Maira G, Sanna A, Serra M, Biggio G. Enhancement of acetylcholine release by flumazenil in the hippocampus of rats chronically treated with diazepam but not with imidazenil or abecarnil. Psychopharmacology. 1995;121(2):180-185.

80. Petursson H, Lader M. Benzodiazepine dependence. Addiction. 1981; 76(2):133-145.

81. Tietz E, Rosenberg H, Chiu T. Autoradiographic localization of benzodiazepine receptor downregulation. J Pharmacol Exp Ther. 1986; 236(1):284-292.

82. Gallager D, Lakoski J, Gonsalves S, Rauch S. Chronic benzodiazepine treatment decreases postsynaptic GABA sensitivity. Nature. 1984; 308(5954):74-77.

83. Zhao T, Chiu T, Rosenberg H. Reduced expression of gamma-aminobutyric acid type A/benzodiazepine receptor gamma 2 and alpha 5 subunit mRNAs in brain regions of flurazepam-treated rats. Mol Pharmacol. 1994;45(4):657-663.

84. Poisbeau P, Williams S, Mody I. Silent GABAA synapses during flurazepam withdrawal are region-specific in the hippocampal formation. J Neurosci. 1997;17(10):3467-3475.

85. Pesold C, Caruncho H, Impagnatiello F, et al. Tolerance to diazepam and changes in GABAA receptor subunit expression in rat neocortical areas. Neuroscience. 1997;79(2):477-487.

86. Arnot M, Davies M, Martin I, Bateson A. GABAA receptor gene expression in rat cortex: differential effects of two chronic diazepam treatment regimes. J Neurosci Res. 2001;64(6):617-625.
87. Kales A, Scharf M, Kales J. Rebound insomnia: a new clinical syndrome. Science. 1978;201(4360):1039-1041.

88. Browne T, Penry J. Benzodiazepines in the treatment of epilepsy: a review. Epilepsia. 1973;14(3):277-310.

89. Bateson A. Basic pharmacologic mechanisms involved in benzodiazepine tolerance and withdrawal. Curr Pharm Des. 2002;8(1):5-21.

90. Schweizer E. Maintenance drug treatment of panic disorder. Arch Gen Psychiatry. 1993;50(1):51-60.

91. Cowley D. Benzodiazepine sensitivity in panic disorder: effects of chronic alprazolam treatment. Neuropsychopharmacology. 1995;12(2): $147-157$.

92. Rijnsoever VC. Requirement of $\alpha 5$-GABAA receptors for the development of tolerance to the sedative action of diazepam in mice. J Neurosci. 2004;24(30):6785-6790.

93. Hawkins M, Pravica M, Radulovacki M. Chronic administration of diazepam downregulates adenosine receptors in the rat brain. Pharmacol Biochem Behav. 1988;30(2):303-308.

94. Hawkins M, Pan W, Stefanovich P, Radulovacki M. Desensitization of adenosine A2 receptors in the striatum of the rat following chronic treatment with diazepam. Neuropharmacology. 1988; 27(11):1131-1140.

95. Kaplan G, Cotreau M, Greenblatt D. Effects of benzodiazepine administration on A1 adenosine receptor binding in-vivo and ex-vivo. J Pharm Pharmacol. 1992;44(8):700-703.

96. Narimatsu E, Aoki M. Involvement of the adenosine neuromodulatory system in the benzodiazepine-induced depression of excitatory synaptic transmissions in rat hippocampal neurons in vitro. Neurosci Res. 1999;33(1):57-64.

97. Narimatsu E, Niiya T, Kawamata M, Namiki A. [The mechanisms of depression by benzodiazepines, barbiturates and propofol of excitatory synaptic transmissions mediated by adenosine neuromodulation]. Masui. 2006;55(6):684-691. Japanese.

98. Tsuda M, Chiba Y, Suzuki T, Misawa M. Upregulation of NMDA receptor subunit proteins in the cerebral cortex during diazepam withdrawal. Eur J Pharmacol. 1998;341(2-3):R1-R2.

99. Tsuda M, Shimizu N, Yajima Y, Suzuki T, Misawa M. Hypersusceptibility to DMCM-induced seizures during diazepam withdrawal in mice: evidence for upregulation of NMDA receptors. Naunyn Schmiedebergs Arch Pharmacol. 1998;357(3):309-315.

100. Bonavita C, Ferrero A, Cereseto M, Velardez M, Rubio M, Wikinski S. Adaptive changes in the rat hippocampal glutamatergic neurotransmission are observed during long-term treatment with lorazepam. Psychopharmacology. 2003;166(2):163-167.

101. Song J, Shen G, Greenfield L, Tietz E. Benzodiazepine withdrawalinduced glutamatergic plasticity involves up-regulation of GluR1containing $\alpha$-amino-3-hydroxy-5-methylisoxazole-4-propionic acid receptors in hippocampal CA1 neurons. J Pharmacol Exp Ther. 2007; 322(2):569-581.

102. File S, Fernandes C. Dizocilpine prevents the development of tolerance to the sedative effects of diazepam in rats. Pharmacol Biochem Behav. 1994;47(4):823-826.

103. Koff J, Pritchard G, Greenblatt D, Miller L. The NMDA receptor competitive antagonist CPP modulates benzodiazepine tolerance and discontinuation. Pharmacology. 1997;55(5):217-227.

104. Fernandes C, File S. Dizocilpine does not prevent the development of tolerance to the anxiolytic effects of diazepam in rats. Brain Res. 1999;815(2):431-434.

105. Steppuhn K, Turski L. Diazepam dependence prevented by glutamate antagonists. Proc Natl Acad Sci U S A. 1993;90(14):6889-6893.

106. Jacob T, Michels G, Silayeva L, Haydon J, Succol F, Moss S. Benzodiazepine treatment induces subtype-specific changes in GABAA receptor trafficking and decreases synaptic inhibition. Proc Natl Acad Sci U S A. 2012;109(45):18595-18600.

107. Hernandez T, Heninger C, Wilson M, Gallager D. Relationship of agonist efficacy to changes in GABA sensitivity and anticonvulsant tolerance following chronic benzodiazepine ligand exposure. Eur J Pharmacol. 1989;170(3):145-155. 
108. Gonsalves S, Gallager D. Persistent reversal of tolerance to anticonvulsant effects and GABAergic subsensitivity by a single exposure to benzodiazepine antagonist during chronic benzodiazepine administration. J Pharmacol Exp Ther. 1988;244(1):79-83.

109. Klein R, Mascia M, Harkness P, Hadingham K, Whiting P, Harris R. Regulation of allosteric coupling and function of stably expressed gamma-aminobutyric acid (GABA)A receptors by chronic treatment with GABAA and benzodiazepine agonists. $J$ Pharmacol Exp Ther. 1995;274(3):1484-1492.

110. Miller L, Heller J, Lumpkin M, Weill C, Greenblatt D, Shader R. Augmentation of GABAA receptor function by chronic exposure to GABA-neutral and GABA-negative benzodiazepine ligands in cultured cortical neurons. Biochem Pharmacol. 1990;40(6):1337-1344.

111. Lugoboni F, Leone R. What is stopping us from using flumazenil? Addiction. 2012;107(7):1359.

112. Savic I. Feasibility of reversing benzodiazepine tolerance with flumazenil. Lancet. 1991;337(8734):133-137.

113. Tietz E, Chiu T, Rosenberg H. Regional GABA/benzodiazepine receptor/chloride channel coupling after acute and chronic benzodiazepine treatment. Eur J Pharmacol. 1989;167(1):57-65.

114. Gutiérrez M, Ferreri M, Gravielle M. GABA-induced uncoupling of GABA/benzodiazepine site interactions is mediated by increased GABAA receptor internalization and associated with a change in subunit composition. Neuroscience. 2014;257:119-129.

115. Tehrani M, Barnes E. Agonist-dependent internalization of gammaaminobutyric acid A/benzodiazepine receptors in chick cortical neurons. J Neurochem. 1991;57(4):1307-1312.

116. Tehrani M, Barnes E. Identification of GABAA/benzodiazepine receptors on clathrin-coated vesicles from rat brain. $J$ Neurochem 1993;60(5):1755-1761.

117. Tehrani M, Barnes E. Sequestration of $\gamma$-aminobutyric acid A receptors on clathrin-coated vesicles during chronic benzodiazepine administration in vivo. J Pharmacol Exp Ther. 1997;283(1):384-390.

118. Tehrani M, Baumgartner B, Barnes E. Clathrin-coated vesicles from bovine brain contain uncoupled GABAA receptors. Brain Res. 1997; 76(1-2):195-203

119. Gravielle M. Activation-induced regulation of GABAA receptors: is there a link with the molecular basis of benzodiazepine tolerance? Pharmacol Res. 2016;109:92-100.
120. Lilly S, Zeng X, Tietz E. Role of protein kinase A in GABAA receptor dysfunction in CA1 pyramidal cells following chronic benzodiazepine treatment. J Neurochem. 2003;85(4):988-998.

121. Ali N, Olsen R. Chronic benzodiazepine treatment of cells expressing recombinant GABAA receptors uncouples allosteric binding: studies on possible mechanisms. J Neurochem. 2008;79(5):1100-1108.

122. Huopaniemi L, Keist R, Randolph A, Certa U, Rudolph U. Diazepaminduced adaptive plasticity revealed by $\alpha 1$ GABAA receptor-specific expression profiling. J Neurochem. 2004;88(5):1059-1067.

123. Auta J, Impagnatiello F, Kadriu B, Guidotti A, Costa E. Imidazenil: a low efficacy agonist at $\alpha 1$ - but high efficacy at $\alpha 5$-GABAA receptors fail to show anticonvulsant cross tolerance to diazepam or zolpidem. Neuropharmacology. 2008;55(2):148-153.

124. Zanotti A, Mariot R, Contarino A, Lipartiti M, Giusti P. Lack of anticonvulsant tolerance and benzodiazepine receptor down regulation with imidazenil in rats. Br J Clin Pharmacol. 1996;117(4):647-652.

125. Ghiani C, Serra M, Motzo C, et al. Chronic administration of an anticonvulsant dose of imidazenil fails to induce tolerance of GABAA receptor function in mice. Eur J Pharmacol. 1994;254(3):299-302.

126. Kadriu B, Gocel J, Larson J, et al. Absence of tolerance to the anticonvulsant and neuroprotective effects of imidazenil against DFP-induced seizure and neuronal damage. Neuropharmacology. 2011;61(8): 1463-1469.

127. Auta J, Guidotti A, Costa E. Imidazenil prevention of alprazolaminduced acquisition deficit in patas monkeys is devoid of tolerance. Proc Natl Acad Sci U S A. 2000;97(5):2314-2319.

128. Vinkers $\mathrm{C}$, van Oorschot $\mathrm{R}$, Nielsen $\mathrm{E}$, et al. GABAA receptor $\alpha$ subunits differentially contribute to diazepam tolerance after chronic treatment. PLoS One. 2012;7(8):e43054

129. Rundfeldt C, Wlaź P, Hönack D, Löscher W. Anticonvulsant tolerance and withdrawal characteristics of benzodiazepine receptor ligands in different seizure models in mice. Comparison of diazepam, bretazenil and abecarnil. J Pharmacol Exp Ther. 1995;275(2):693-702.

130. Sanna E, Busonero F, Talani G, et al. Low tolerance and dependence liabilities of etizolam: molecular, functional, and pharmacological correlates. Eur J Pharmacol. 2005;519(1-2):31-42.

131. O'Connell C, Sadler C, Tolia V, Ly B, Saitman A, Fitzgerald R. Overdose of etizolam: the abuse and rise of a benzodiazepine analog. Ann Emerg Med. 2015;65(4):465-466.
Neuropsychiatric Disease and Treatment

\section{Publish your work in this journal}

Neuropsychiatric Disease and Treatment is an international, peerreviewed journal of clinical therapeutics and pharmacology focusing on concise rapid reporting of clinical or pre-clinical studies on a range of neuropsychiatric and neurological disorders. This journal is indexed on PubMed Central, the 'PsycINFO' database and CAS,

\section{Dovepress}

and is the official journal of The International Neuropsychiatric Association (INA). The manuscript management system is completely online and includes a very quick and fair peer-review system, which is all easy to use. Visit http://www.dovepress.com/testimonials.php to read real quotes from published authors. 